\title{
El cine o la vida: Narraciones del yo en Mapa (Siminiani, 2012)
}

\section{Zinema edo bizitza: ni-aren narrazioak Mapa filmean}

\author{
Cinema or life: Narratives of the self \\ in Mapa (Siminiani, 2012)
}

\section{Andrea Kaiser Moro'}

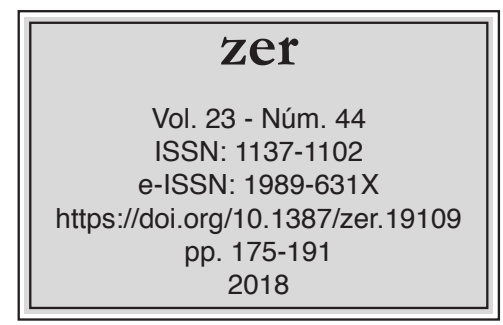

Recibido el 31 de enero de 2018, aceptado el 14 de mayo de 2018.

\section{Resumen}

El presente artículo aborda el giro intimista que el cine documental ha experimentado en las últimas décadas en España. Se pretende identificar las estrategias estéticas y narrativas que caracterizan al documental en primera persona, así como sus dificultades de implementación en España debido al valor socio-histórico del género. Como caso de estudio se analiza la película Mapa (Siminiani, 2012) como práctica discursiva donde se encuentran, de manera indisociable, lo cinematográfico y la vida del autor. Mediante esto se pretende arrojar luz sobre la ambigüedad genérica del film, a caballo entre el road movie, el diario filmado y la autoficción.

Palabras clave: documental; autobiografía; autoficción; cine español.

\section{Laburpena}

Artikulu honek zinema dokumentalak Espainian urte hauetan egin duen bira intimista du hizpide. Ildo horretatik, lehen pertsonako dokumentalak berezko dituen estrategia estetiko eta narratiboak identifikatu nahi dira, baita Espainian generoaren balio sozio-historikoaren ondorioz zinema mota hori finkatzeko izan ziren zailtasunak ere. Ikergai gisa, Mapa (Siminiani, 2012) pelikula aztertzen da; izan ere, diskurtso-praktika horretan, elkarrekin topo egiten dute alderdi zinematografikoak eta autorearen bizitzak, modu bereizezinean. Horren bidez, argi egin nahi da filmaren genero-anbiguotasunean, road movie-aren, egunkari filmatuaren eta autofikzioaren artean baitago.

Gako-hitzak: dokumentala; autobiografia; autofikzioa; espainiar zinema.

\footnotetext{
${ }^{1}$ Universidad de Granada, andreakaiser@correo.ugr.es
} 


\begin{abstract}
This article assesses the intimate shift that documentary film has experienced in the last decades in Spain. The aim is to identify the aesthetic and narrative strategies that characterize the first-person documentary, as well as its implementation difficulties in Spain due to the socio-historical value associated with the genre. As a case study, the film Mapa (Siminiani, 2012) is analyzed as a practice where the cinematographic and the life of the author are inextricably linked. This is intended to shed light on the generic ambiguity of the film, between the road movie, the filmed diary and auto-fiction.
\end{abstract}

Keywords: documentary; autobiography; autofiction; Spanish cinema. 


\section{Introducción}

Gracias a la popularización del digital, la autorrepresentación ya no es un privilegio del artista ante el espejo. El acto de girar la cámara hacia dentro ha dejado de ser el lujo de unos pocos para convertirse en un instrumento compartido por buena parte de la sociedad. La llegada al mercado de smartphones y pequeñas videocámaras digitales, cada vez más ligeras y con mejores prestaciones, ha constituido un paso decisivo en la expansión de las narrativas audiovisuales en primera persona (Corbett, 2016).

Pero este desplazamiento de lo íntimo al exterior no sólo acontece en el selfie y las redes sociales. Los dominios de la primera persona también se han extendido a la ficción televisiva y cinematográfica. En los últimos años se ha popularizado toda una serie de productos donde su creador ficcionaliza su biografía en la narración: series como Louie (FX: 2010-2015), Girls (HBO: 2012-2017) o Please like me (Josh Thomas: 2013-2016) son prueba de la creciente buena acogida de la autoficción. Del lado del cine nos encontramos a jóvenes directores como Xavier Dolan, Miranda July o Valeria Bruni-Tedeschi, en cuyas ficciones acontece la ambigua identificación entre autor, director y personaje característica del pacto autoficticional (Lejeune, 1994).

Este artículo se propone reflexionar cómo afecta este giro intimista (Martín Gutiérrez, 2008) a la práctica del cine documental español, que en los últimos años ha experimentado una progresiva incorporación de la subjetividad como rasgo característico de su discurso. Considerado el género de la tercera persona por excelencia, desde hace una década se viene señalando su apertura incorporando el yo como elemento de enunciación (Quílez, 2008; Piedras, 2010; I. Gómez, 2015), siendo en la actualidad una práctica cada vez más popular en España tanto en términos de público como de recepción.

No obstante, desde los años sesenta del siglo pasado la narración en primera persona es un nudo esencial del cine documental: el trabajo del Jonas Mekas en Walden: Diaries, Notes and Sketches (1969) constituyó la inauguración del diario filmado estadounidense, continuado por cineastas europeos como Chantal Akerman, Johan van der Keuken o Wim Wenders, cuya experimentación formal y narrativa supusieron una renovación del documental análoga a la que artistas como Jackson Pollock, John Cage o Allen Ginsberg desarrollaron en pintura, música y literatura, respectivamente (Lane, 2002). En estos films no es extraño que la narración tome la estructura canónica del viaje o la búsqueda personal (como demuestran los trabajos de Jonas Mekas, Ross McElwee o Frank Cole) siendo la tensión entre la imposibilidad de alcanzar una integridad total en las historias que los cineastas cuentan sobre su vida y el intento por reconstruirlas desde el film uno de los elementos clave del éxito en la recepción de estas obras (Forceville, 2006).

También se ha vinculado esta práctica fílmica a las claves conceptuales de la posmodernidad: desde que el pensamiento posmoderno lanzara sus sospechas sobre la posibilidad de distinguir entre imágenes y realidad, la inestabilidad de la memoria y la historia han funcionado como categorías de partida de la práctica cultural y artística contemporánea (Corbett, 2016). Así, la imposibilidad de confiar plenamente en las grabaciones de la historia es una noción fundamental para el documentalista posmoderno, que emprende la recreación de su historia personal desde la conciencia de la naturaleza fugaz de la historia y la memoria. 
El caso español es especialmente llamativo ya que hasta el año 2000 no hay registro de un sólo film autobiográfico (Torreiro, 2010). El peso de la dimensión social e histórica del género parece haber tenido una función determinante a la hora de mantener al margen la enunciación en primera persona (De la Torre, 2015). Pese a que esta concepción, de corte más conservador, se transformó en los años setenta con el cine de Jonas Mekas, Chantal Akerman o Ross McElwee (Font, 2008) no sería hasta el nuevo milenio que este cambio se implementó en España.

Las causas de este fenómeno apuntan a la lenta integración de la influencia exterior en el periodo tardofranquista español (De la Torre, 2015; I. Gómez, 2015). Tres circunstancias tuvieron que entrar en juego para impulsar este giro: la constitución en 1997 del Máster de Documental de Creación de la Universidad Pompeu Fabra, la divulgación de cine alternativo por parte de festivales y filmotecas de cine y la asunción del reality show al imaginario popular (Piedras, 2010). Este cambio fue llevado a cabo por reconocidos documentalistas como Joaquim Jordà (Monos como Becky, 1999) o José Luis Guerín (Guest, 2011), quienes se incorporarían progresivamente a sí mismos como parte de sus narraciones. En la actualidad asistimos a lo que Efrén Cuevas definió como "el lento despertar del documental autobiográfico" (2010: 106) a través de una corriente de nuevos directores que, gracias a las posibilidades del digital, han colocado la subjetividad en el centro de su representación.

A este respecto es relevante destacar el reciente éxito del documental Muchos $h i$ jos, un mono y un castillo (Salmerón, 2017) como una de las producciones que consagran la introducción de la primera persona en el documental de autor español: un éxito para el público y la crítica que recientemente obtuvo el Goya a Mejor Película Documental (2018) y que confirma la positiva aceptación del documental familiar y subjetivo en los canales más populares del cine documental. En la misma línea, los proyectos fílmicos de Andrés Duque (Color perro que huye, 2011), Elías León Siminiani (Mapa, 2012), Ion de Sosa (True Love, 2013) o David Gutiérrez Camps (The Juan Bushwick Diaries, 2013) han experimentado durante la última década con las posibilidades narrativas de la autoficción y la autobiografía.

\section{Objetivos y metodología}

Este artículo es fruto de una investigación cualitativa y en su desarrollo se han empleado herramientas teóricas pertenecientes a la narratología comparada, los estudios intermediales, la teoría literaria y la teoría fílmica. Se pretende identificar los recursos narrativos y estéticos que, desde la especificidad del cine, caracterizan a la narración documental en primera persona. Para ello se emprende un análisis de contenido de Mapa (Siminiani, 2012) y se aborda su discurso empleando la noción bajtiniana de alteridad como herramienta de análisis. Con esto se pretende reflexionar sobre las estrategias narrativas de la película: en concreto, sobre el modo en que el cineasta representa su conflicto interno mediante el desdoblamiento del discurso del narrador. Para sistematizar los resultados obtenidos se ha generado una ficha de análisis que contempla las siguientes variables: aspectos narrativos del film (concediendo especial atención al discurso verbal del protagonista, que a través del relato en off ancla su subjetividad en la película) función y usos de las imágenes (donde se analiza el papel de los recursos empleados para generar veracidad, la puesta 
en escena de la corporalidad del cineasta y el valor que concede a las imágenes etnográficas de su viaje a la India), así como aspectos temáticos del film (donde se propone una lectura interpretativa de los aspectos anteriormente citados). Estas categorías permiten estudiar las estrategias que Siminiani pone en marcha a la hora de constituirse como personaje.

En base a los precedentes anteriormente descritos, se plantean las siguientes hipótesis:

1. La comprensión lúdica y performativa de la práctica documental es el detonante de la peripecia personal de León Siminiani y del film Mapa.

2. La auto-parodia, la ironía y la estética del fracaso son los registros clave desde donde el director de Mapa aborda su autorrepresentación, promoviendo una comprensión de sí mismo como personaje cuyos efectos inciden en los acontecimientos de su propia vida.

3. La figura del "otro" permite a León Siminiani objetivar sus contradicciones internas desde la distancia de un alter ego-personaje, demostrando la función reparadora del diario filmado.

4. Las estrategias formales que anclan la enunciación en primera persona en el discurso de Mapa son la focalización interna fija y la narración en off.

Asimismo, en la constitución del marco teórico se ha realizado una revisión bibliográfica atendiendo a las aportaciones de la noción de alteridad del teórico ruso Mijaíl Bajtín (1963) y las reflexiones sobre la actualidad de su pensamiento de SánchezMesa $(1999,2017)$ y Arfuch (2006). Por otra parte, se entienden como referencia los estudios realizados en torno al documental en primera persona de Font (2008), Cuevas (2010), Piedras (2010) y Lagos (2011), así como las consideraciones de Lejeune (1994), Alberca (2007), Pozuelo Yvancos (2013) y Casas (2014) sobre autobiografía y autoficción.

\section{Marco teórico}

Filmar la propia vida es una práctica que, gracias a su demarcación de las estructuras comerciales, permite al cineasta dar cuenta de su cotidianidad empleando los beneficios del do it yourself. Asociada a la poco frecuente oportunidad de filmar una película en soledad, esta práctica se concibe como un ejercicio artesano y solitario cuya atención hacia lo íntimo restaura, para el cineasta, cierta reconexión con el mundo.

Parece razonable comprender la filmación de un diario como parte de una estrategia de su autor para incidir (por la presencia de la cámara y sus consecuencias) sobre su vida y sus relaciones con los otros (Bergala, 2008). Si de algo son prueba las obras de este género es que conceden a los cineastas la oportunidad de vivir algo que no habrían vivido sin la coartada del film, sustituyendo el tradicional modo 
observacional del género por una propuesta performativa (Weinrichter, 2004). Así lo demuestra el trabajo de Jonas Mekas, Ross McElwee o David Perlov: la cámara funciona como una prolongación de sí mismos capaz de conducirles a experiencias que sin la cámara no habrían conocido -como ejemplo, la cineasta Sophie Calle llegó a contraer matrimonio en No sex last night (1996) como consecuencia del periplo de la película-. Asumiendo que en estos casos la filmación no puede disociarse de la vida personal de su autor (Font, 2008) resulta verosímil entender el cine en primera persona como una toma de posición: ante las imágenes y la vida.

Entendiendo que siempre existe una dimensión del autor que permanece fuera de campo -sea su intención estética si actúa ante la cámara, o su cuerpo si sólo filma- este tipo de narraciones también constatan la incapacidad de una emisión comunicativa plena (Quílez, 2008). Filmar en primera persona es siempre un modo de renuncia y de pérdida: una impotencia que no pertenece en exclusiva al cine sino a cualquier narración constituida desde los límites del yo. Con esto me refiero a la imposibilidad de ser narrador homodiegético y heterodiegético a la vez, construyendo una narración que esté fuera y dentro de la historia. También se ha defendido que dicha imposibilidad no es suficiente para negar el valor biográfico de una historia (Cuevas, 2010), pues son numerosas las opciones formales con las que el cineasta puede anclarse en el film. Sorprendentemente no es tanto el rodaje como el montaje la fase donde se ancla el yo del cineasta, entendido como auténtico orquestador del relato. Sería éste el lugar de construcción de un yo que ha vivido y que elabora un segundo yo, creado en la experiencia de ensamblaje de planos.

Para clarificar el territorio terminológico en el que nos situamos, este artículo propone una modesta tipología que distingue las siguientes formulaciones del yo en el cine documental (admitiendo lo difuso entre sus límites):

1. Autobiografía: narración caracterizada por la promesa de veracidad de su autor. Con independencia del ajuste entre factualidad y narración, el autor se compromete a relatar hechos y memorias que pertenecen a su vida. En ella se encuentran distintas modulaciones:

1.1..Diario filmado: narración donde el presente del autor se incorpora al film, entendido como devenir y sucesión de acontecimientos. Dado que la filmación se constituye generalmente sin plan previo, el relato se vincula al presente de forma inmediata, generando un fuerte vínculo entre filmación y vida. El relato se constituye a partir de fragmentos sucedidos cronológicamente donde lo narrativo fija un marco de referencia mínimo.

1.2. Diario de viajes: modalidad del diario filmado centrado en el esquema del viaje (punto de partida, trayectoria y destino) que formalmente reescribe las convenciones del road movie de ficción. Habitualmente toma la forma de búsqueda identitaria del autor, que emprende un viaje en busca de resolver aspectos conflictivos de su vida (retorno al país o al hogar de origen, búsqueda de familiares desaparecidos 
o desconocidos, reconstrucción de la genealogía familiar, relaciones sentimentales sin resolver). El desplazamiento geográfico se convierte en alegoría del viaje interior que experimenta el cineasta.

1.3. Memorias: narración retrospectiva donde el pasado del autor es reconstruido con un fuerte peso narrativo. A diferencia del diario filmado, la distancia temporal entre el pasado del autor y el comentario de la narración favorece la reflexión y generación de nuevas capas de sentido en el film.

2. Autoficción: narración cuya clave reside en la ambigüedad de su pacto con el receptor (Doubrovsky, 1977). Al contrario que en la autobiografía, el autor se mantiene en silencio y no reconoce explícitamente su compromiso con lo relatado. Yvancos (2013) y Alberca (2007) han empleado el término para designar aquellos relatos que se presentan como ficción pese a su apariencia autobiográfica, es decir, aquellos en los que se produce una identificación entre autor, narrador y personaje (Alberca, 2007). La autoficción propone un doble pacto que integra el pacto novelesco (pues se presenta paratextualmente como texto de ficción) pero mantiene latente el pacto autobiográfico a través de la identidad nominal entre autor y personaje. En este artículo apostamos por situar a Mapa (2012) en lo que Vicent Colonna (2004) definió como autoficción autorial, dado el modo en que su autor ejerce de comentarista y verificador de las imágenes que se desarrollan en el film.

Desde que el pensamiento posmoderno anunciara la fragmentación del sujeto y la imposibilidad de pensar la identidad como una unidad estable y fija (Lindig, 2009; Casas, 2014) la noción de alteridad no sólo ha servido para identificar fenómenos externos sino también para dar forma a las contradicciones internas de cualquier personaje: de ahí la persistencia de dobles, desdoblamientos y doppelgangers en los textos de nuestra cultura. Este artículo recoge el testigo de esta tradición y se interroga por la representación de este motivo en el cine documental más reciente: en concreto, en el film español Mapa (Siminiani, 2012).

\section{El "otro" como motivo narrativo}

Parte de la pulsión que funda la narración en primera persona se relaciona con la intención de identificar estados de ánimo potencialmente desestabilizadores para quien los padece. De ahí que se haya señalado la función reparadora de la autobiografía, en tanto que "apoyo psíquico nada despreciable contra algo que amenaza al sujeto en su integridad" (Bergala, 2008: 28). También ha sido asociada con la fijación de una identidad a la deriva (Imbert, 2010) y la desubicación del individuo tras la caída de la modernidad (Font, 2008). Por esta razón se insiste en que toda narración del yo aparece, en sus diversas manifestaciones, "como una posición enunciativa dialógica, en constante despliegue hacia la otredad del sí mismo" (Arfuch, 2006: 99). Estos 
acercamientos nos permiten pensar el cine en primera persona como la construcción de un discurso en diálogo con una suerte de alteridad, ya sea externa o interna.

La noción de alteridad es una herramienta relevante para entender esta práctica discursiva. En este sentido resultan pertinentes las reflexiones del teórico ruso Mijaíl Bajtín, dada la utilidad con que admiten ser proyectadas sobre situaciones comunicativas contemporáneas. Sánchez-Mesa y Baetens (2017) señalaron recientemente el modo en que un enfoque dialógico permite poner en marcha una perspectiva diferencial en el estudio de las transferencias entre y a través de medios de comunicación, y desde este trabajo esta sensibilidad es asumida como punto de partida en tanto que atiende a las fricciones que suceden tanto a nivel inter- como intramedial, sin perder de vista la especificidad de cada medio.

Para este artículo resulta relevante la dinámica dialógica del pensamiento bajtiniano, traducida en el intento por dilucidar "las formas en que las partes se relacionan a la hora de formar un todo, la forma en que un enunciado lingüístico, un sujeto o una cultura no pueden ser comprendidas sino en relación con sus otros correspondientes" (Sánchez-Mesa, 1999: 13). El sujeto es necesariamente proceso para Bajtín: una actividad en transformación y orientada positivamente hacia un otro que le constituye y al que constituye. Bajtín valoró de un modo tan decisivo esta orientación que su noción de sujeto es la resultante creativa de este intercambio: algo que llega siempre después y en forma de respuesta: "La palabra propia se elabora gradual y lentamente a partir de las palabras ajenas reconocidas y asimiladas, y, en un principio, casi no se distinguen las fronteras entre ellas" (Bajtín, 1975: 161). El sujeto bajtiniano se prueba así radicalmente social, "definido por su interacción con los demás y no por su condición deseante o su carencia de ese otro" (Sánchez-Mesa, 1999: 264). En cierto sentido es el contacto y la respuesta activa a este input lo que constituye al sujeto como réplica creativa a los contenidos que ha incorporado. De este modo, Bajtín señala positivamente una alteridad dentro del interior del mismo sujeto, que es en sí mismo diálogo, relación yo/otro.

En un sentido más amplio es evidente que la noción del otro es ya un mito de nuestra cultura -y también de la teoría del arte-, tradicionalmente empleado para representar lo contradictorio e inaprehensible dentro y fuera de nuestros márgenes. De algún modo ha dado forma a lo desconocido del mundo exterior (bárbaros, monstruos, enfermedades) y lo escindido de nuestra interioridad: interrogantes que siempre se desea recuperar bajo una comprensión plena. Edgar Morin definió el otro como "otro ego, o más exactamente un alter-ego que el vivo siente en sí, a la vez exterior e íntimo, durante toda su existencia" (1970: 145) señalando la paradoja de algo que se experimenta permanentemente dentro y fuera de sí. En sus reflexiones sobre la noción de sujeto Michel Foucault identificó esta idea como "indispensable en la práctica de uno mismo para que la forma que define esta práctica alcance efectivamente su objeto, es decir, el yo" (1994: 131). A la luz de esta idea el otro no sólo es un símbolo externo que representa contradicciones internas sino una suerte de bastón antropológico: la condición de posibilidad de un sujeto que pretende afirmarse como tal.

El documental en primera persona articula diferentes modulaciones de esta experiencia del otro simultáneamente exterior e íntimo. En Los espigadores y la espigadora (Varda, 2000) su directora, Agnès Varda, reflexiona sobre la vejez como un 
proceso que extraña, desdobla y secuestra su capacidad para reconocerse a sí misma, siendo el film el debate entre la imagen que cree tener de sí frente a la imagen que en realidad tiene. En esta línea, la enfermedad y la muerte también se representan mediante la figura de la otredad, tal y como demuestra el documental Irène (2009), de Alain Cavalier, un diario filmado donde el autor dialoga con la desaparición de su esposa Irène Tunc, fallecida cuarenta años atrás, interactuando con la presencia fantasmal de su recuerdo. En la misma línea, Tarnation (Jonathan Caouette, 2004), lleva al extremo la idea de otredad al presentar el autorretrato de un cineasta cuya personalidad está escindida. Caouette, enfermo de trastorno mental de despersonalización, salta de una auto-narración en primera persona a otra en tercera para retratar no sólo el estado esquizoide de su madre, sino su pánico a parecerse a ella. A la hora de hablar de su historia familiar, el director se desdobla y refiere a sí mismo como si se tratara de un personaje de una película de terror. Otra de las estrategias de representación de esta otredad de sí es la apropiación de una identidad exterior, es decir, la conversión del otro en un doble de mí mismo. Sherman's march (Ross McElwee, 1986) nos muestra a un director que resuelve su dificultad para hablar de sí mismo poniendo a otro en su lugar: en este caso, al protagonista de la parte etnográfica de su documental, el general Sherman.

En la española True love (2011) su director, Ion de Sosa, aborda el duelo de su ruptura amorosa desde una distancia espectatorial. En esta película asistimos a una representación de su intimidad que excluye el anclaje verbal del yo, renunciando a incorporar voces en off o menciones directas a su yo. Sólo queda la exposición del cuerpo del cineasta, que eventualmente se muestra, silencioso, en consultas médicas que indagan en su cuerpo de un modo u otro. De Sosa renuncia a verbalizarse en favor de la elocuencia de su condición de paciente y personaje, difuminándose en un diario en el que no hay afirmación de la identidad, sino tan solo habitaciones, calles y silencios de un Berlín que se repite de forma mecánica. True love recorre el camino de lo informulable: el ensimismamiento donde se ha disuelto toda concreción del yo.

\section{Elías León Siminiani: el permiso de ser uno mismo}

Entre los nombres de Carlos Vermut, Isaki Lacuesta o Jonás Trueba como claves de un cine español que actualmente juega con ficción y no ficción se sitúa el cántabro Elías León Siminiani (Santander, 1971). Este cineasta ha trabajado como guionista en televisión y durante años ha elaborado cortometrajes de no ficción, alzándose con más de cincuenta galardones internacionales hasta la fecha. Hace seis años su largometraje Mapa (2012) fue nominado a mejor documental en los premios Goya 2013.

Siminiani es un director de cine y también un delator: un soplón autorreferencial que en sus películas confiesa cualquier duda cinematográfica, ya se trate de la elección de un encuadre, el objeto de la filmación o el tono de la narración en off. Su obra es una exposición continua de sus reflexiones como cineasta pero también como hombre: cuestiones imposibles de disociar para quien comprende la vida cinematográficamente. En este sentido, su práctica como director se halla en estrecha relación con la comprensión de sí mismo: 
Tal y como yo lo entiendo, el cine en primera persona tiene que ver con el permiso, el permiso de ser uno: permitirse el propio contenido (es decir, la propia vida como material fílmico), permitirse un lenguaje y métodos de trabajo propios, y permitirse la propia forma de relacionarse con el cine (Siminiani, 2012: 98).

Pensar una película es, en este sentido, una excusa para pensar la vida y también la propia identidad: un ejercicio donde la confesión metacinematográfica no sirve al deseo de mostrar las costuras del film sino a la reflexión sobre la manera de estar en el mundo. Su filmografía representa el proceso de incorporación progresiva del yo análogo al experimentado por el documental en España. Esta primera persona se enuncia explícitamente en el cortometraje Límites: $1^{a}$ persona (2009), donde Siminiani asocia la pasión amorosa a los peligros del discurso cinematográfico. Se trata de una obra que aborda la manipulación del lenguaje fílmico revisando las imágenes tomadas para Zoom (2005): un cortometraje cuyas imágenes del cineasta y su por entonces pareja constituían la prueba fehaciente de su amor. Revisando los mismos planos en Límites: $1^{a}$ persona Siminiani encuentra la evidencia de la ruptura que poco después atravesarían. Haciendo uso de la voz en off el autor reflexiona sobre el uso al que pueden someterse los planos durante la fase de montaje (A. Gómez, 2015). Con ello logra desmontar dos ilusionismos, el cinematográfico y el amoroso:

Repitiendo estratégicamente ciertos momentos hice hincapié en detalles que, a la luz del texto, tomaban un significado opuesto al que tenían cuando se grabaron. Y así, invirtiendo el sentido de las imágenes, llegué a convencerme de que efectivamente en el desierto nos habíamos querido a través de la cámara. Yo grabándola y ella dejándose grabar (Siminiani, 2000).

\section{Estudio de caso: Mapa}

\subsection{Ficha técnica}

Título: Mapa.

Año: 2012.

Duración: 85 min.

País: España.

Dirección: Elías León Siminiani.

Guion: Elías León Siminiani.

Reparto: Elías León Siminiani, Ainhoa Ramírez.

Productora: Avalon / Pantalla Partida.

Género: Documental. 


\subsection{Aspectos narrativos}

El film Mapa nace de una crisis vital: León Siminiani es despedido de su trabajo en televisión y pone fin a su relación con quien era su pareja en Zoom (2005). Impulsado por estos cambios retoma su sueño de hacer cine y emprende un viaje a la India que es también la excusa de una película: una historia de amor, un diario de viajes y un ensayo sobre la vida. La ambigüedad genérica de Mapa dificulta una definición unívoca del film, cuyo anclaje subjetivo ha sido situado en la naturaleza híbrida de un documental que "contiene numerosas rupturas con la no ficción" (A. Gómez, 2015: 364) pues utiliza una estructura clásica ficcional para narrar un periplo personal. Como anteriormente se ha descrito, Mapa se sitúa en un territorio intersticial al incorporar rasgos propios de distintas categorías: concretamente, del diario filmado, el diario de viajes y la narración autoficcional.

El motivo del viaje a la India se convierte, así, en un doble detonante: de la película y de la aventura personal. La permeabilidad entre relato y vida es en este sentido absoluta, pues la película exige una progresión dramática cuyo autor demanda personalmente. Hacer una película soluciona, así, la falta de argumento de la vida. Y con ello se establece la paradoja: la vida es el contenido de Mapa y Mapa es el contenido de la propia vida.

León Siminiani se presenta empleando la narración en off: "Me llamo Elías León Siminiani, tengo 37 años y trabajo dirigiendo series de televisión juveniles para la tele. En realidad, yo siempre quise hacer cine"2. Esta aparición se combina con la renuncia a aparecer en pantalla: la autorrepresentación oblicua del director se inaugura con una sucesión de planos de objetos íntimos. Su identidad se infiere a partir de los objetos, enseres y recuerdos que remiten a su pasado y su personalidad. Durante esta introducción León Siminiani resume su biografía: su complicada relación con el cine, su reciente ruptura amorosa y su decisión de marchar a India.

Mapa establece un diálogo especular con todo tipo de imágenes ajenas y, en consecuencia, se identifica con una alteridad en ocasiones exterior y a veces interior. Existe, así, una proyección continua del protagonista sobre el mundo, donde lo filmado se convierte en prueba y espejo de su propia conflictividad interna. El director descubre partes esenciales de su personalidad mientras interroga su entorno y coquetea con la tradición del cine etnográfico, siempre con cautela y renunciando a valorarlo políticamente: así, como si sólo fuera posible hablar de uno mismo, Siminiani evita narrar la miseria de la India. La conciencia de sus limitaciones y la creencia en su falta de legitimidad le impide narrar nada que no sea él mismo: el paisaje exterior sólo puede servir como paisaje interior. Así, entendiendo su propia identidad en sentido espacial, el paisaje y las gentes de India pasan a convertirse en ilustración del conflicto interno. La identificación es tal que la imagen adquiere el valor de herramienta de autoconocimiento. En una de las secuencias donde Siminiani se confiesa perdido, afirma:

Las imágenes se rebelan contra mí. Como la libertad de este chico nadando al amanecer, transformada en el mismo plano en la angustia de la muerte que llevo días evitando. En realidad, soy yo el que nada, el que corre contra la tormenta al querer dar la espalda a la muerte, al querer ignorar mi angustia (2012).

Ibídem. 
En este sentido, el yo de Mapa es textualidad pura: un narrador-enunciador y un comentarista de la vida. Frente a la focalización externa tradicionalmente asociada al meganarrador fílmico (Gaudreault y Jost, 1995) la narración de la película es a la vez externa e intradiegética pues existe una ambigua identificación entre narrador, director y personaje. Así, las tomas de la India muestran las costumbres y tradiciones del país al tiempo que se engarzan al propio Siminiani vía relato en off: el país se conecta, así, con la peripecia vital y se convierte en espejo de la incertidumbre del cineasta. Al presentar todos los acontecimientos filtrados a través de su conciencia, el relato presenta una focalización interna fija (Genette, 1989) de manera que el espectador se desenvuelve en un nivel cognitivo análogo al personaje.

Es evidente que la narración en off funciona como anclaje autobiográfico en Mapa: si no fueran comentadas por Siminiani, las tomas de la India, Madrid o Santander resultarían ajenas, observacionales y distantes: podrían, incluso, pertenecer a un documental de viajes. Aunque ciertos planos de Mapa sean claramente subjetivos (ya sea por el temblor de la cámara o su posición respecto a lo observado) la mayoría de las tomas no remiten directamente al pulso del director. Paradójicamente, es a través de la palabra que Siminiani recrea la sensación de una mirada: así, el carácter objetivista del documental es cuestionado por el comentario narrativo, responsable de situarlo en un terreno autobiográfico. El discurso en off altera la comprensión de lo que la cámara muestra y lo atribuye a la visión del ojo-cámara de Siminiani.

\subsection{Aspectos temáticos}

Mapa no sólo tematiza su proceso de construcción sino el padecer de su director en el camino. Indeciso, frustrado y en clara sintonía con la tradición autoficcional del Woody Allen o el Nanni Moretti más histriónicos, el cineasta se auto-sabotea y critica hasta la parálisis. La mecha se prende ante un dilema ético: el de la filmación de la India. El cineasta se cuestiona si es posible hacerlo sin que el intento sea ridículo, falso o etnocéntrico. Así, si intenta filmar la arquitectura se censurará a sí mismo por banal; si se atreve a registrar su pobreza, se considerará cínico. Mientras filma a una mujer desnuda por la calle, León Siminiani se dice con ironía: “¿Quién eres tú para grabar a esta mujer, aunque le pongas un cuadrado negro? ¿Quién eres tú para hablar de la miseria de la India?" 3 . Lo mismo sucede cuando, de regreso a España, Siminiani se descubre incapaz de filmar el reciente $15-\mathrm{M}$. El director se recrea en un ataque hacia sí mismo en el que se reprocha patético, cínico y sentimental:

¿Pero en qué estás pensando? La miseria de la India o el paro de España no son un comodín, no son un as en la manga para reconducir tu película personal. Tú no eres nadie para grabar el paro, ni la miseria ni la crisis. No me seas farsante haciéndote el cineasta social (Siminiani, 2012).

Esta lucha interna genera en Siminiani una escisión que le obliga a desdoblar su propio discurso. Aquí entra en escena un personaje llamado Otro: una nueva voz

3 Discurso de León Siminiani en la narración en off de Mapa (Siminiani, 2012). 
que reúne todas las autocríticas que vienen boicoteando al director. En este extraño narrador también existe una función positiva, pues libera parcialmente a Siminiani externalizando su conflicto interno.

Este desdoblamiento del director se representa a través de un desdoblamiento de la voz narrativa. En una de las secuencias de máxima confusión sobre la legitimidad de seguir grabando la India, Siminiani calla repentinamente: el Otro suspende la película. La imagen se desplaza súbitamente a negro y la narración en off se silencia. Como si de un rehén se tratara, Siminiani narra con intertítulos su encrucijada: "Hoy, 19 de mayo, después de mucho intentarlo, consigue callarme el Otro, la parte de mí que me confronta" 4 . El texto nos informa de la incapacidad de su director para continuar: el Otro ha silenciado la voz del hombre y del cineasta, convirtiendo la película en su propia negación.

Es iluminador advertir cómo los canales expresivos del relato audiovisual (imagen, sonido y palabra, Gaudreault, 1995) se movilizan para representar la alteridad interior del protagonista. Lo relevante a este respecto es identificar cómo la incapacidad del cineasta para superar sus problemas se traduce en una invalidez para asumir ciertos registros comunicativos: en concreto, el de la representación de su propia voz. Este desdoblamiento también nos permite recuperar las ideas de Batjín (1986) en torno al dialogismo y la concepción del sujeto como diálogo en sí, relación yo-otro. Escindida de sí mismo pero asumida dentro de una compleja polifonía interior, Siminiani dialoga en Mapa con la voz del Otro que, pese a situarse fuera de sí, afecta a su propio discurso. El uso del desdoblamiento se revela terapéutico para el narrador pues le permite continuar la película desplazando su peor yo a una entidad representable y que por tanto le resulta gobernable. La generación de este nuevo personaje concede a Siminiani la oportunidad de esbozar una caricatura de sí mismo: y también, la posibilidad de establecer distancia respecto a su propia crisis.

\subsection{Aspectos formales y función de la imagen}

Son especialmente relevantes dos escenas en que Siminiani se deja ver ante la cámara. La primera tiene lugar horas después de sufrir un accidente de coche: el cineasta se descubre ileso en la cama del hospital y comienza a filmar su rostro. En este momento de desconcierto, León Siminiani ofrece un primer plano de su asombro y se muestra incapaz de pronunciar una palabra sobre lo sucedido. Asistimos al cineasta mirándose al espejo, enfrentándose a sí mismo y asumiendo que incluirse en la acción que acaba de padecer es más importante que narrarla. Siminiani se deja ver como personaje y renuncia así a la palabra.

El resto de escenas en que el cineasta se muestra ante la cámara guardan en común el empleo de estrategias de autorrepresentación oblicuas. En este sentido Siminiani es experto en jugar al escondite con su propia imagen y sólo dejarse ver a través de la propia sombra. El contraluz es, a este respecto, el recurso estrella del cineasta para desvelarse a sí mismo a la vez que permanece considerablemente oculto. La repetición estructural de estos motivos invita a la reflexión sobre los límites de la propia autorrepresentación: como si el autorretrato no pudiera llevarse a cabo

\footnotetext{
${ }^{4}$ Intertítulos de Mapa (Siminiani, 2012).
} 
de manera total y definitiva, y sólo pudiera generar nuevas incertidumbres acerca de quien se sitúa frente a la cámara.

La última ocasión en que Siminiani aparece en pantalla transcurre en la escena final de Mapa. El director concluye que la solución a su atolladero descansa, finalmente, en regresar a la India: solo y sin ínfulas románticas, el cineasta confiesa su arrepentimiento por creer que la salvación de sí mismo descansaba en el amor y las relaciones de pareja. La secuencia final de Mapa delata esta drástica transformación: en un gesto que condensa el sentido de la historia Siminiani permite que Ainhoa, su ex-novia, tome la cámara y le grabe mientras toma sus maletas y abandona la casa:

Mapa empieza conmigo saliendo a grabar, y termina en un sitio donde es la propia vida la que dicta la historia. Por ejemplo, cuando tuve el accidente, a los dos o tres meses decidí que sería un punto de giro. Así que, cuando decido que el accidente entra, se ordena toda la película retroactivamente. Las decisiones de qué entra en la película las toma la vida. (Siminiani, 2012).

En este movimiento el autor renuncia a su condición de director para actuar en su película, lo que en este caso equivale a decir que elige actuar en su propia vida: "Como quiero hacer las cosas de otra forma desde el principio, le he pedido a Ainhoa que grabe la salida"5. En este sentido la película es la aceptación de Siminiani de aquello que escapa a su control: ya sea el contenido del encuadre, la evolución del relato cinematográfico o el propio azar que contienen sus decisiones. Mapa condensa el proceso en que su director accede, así, a dejarse afectar por la vida.

\section{Conclusiones}

La industria audiovisual asiste en nuestros días a un despertar de la subjetividad. La ficción televisiva y cinematográfica acoge nuevas formas de introspección, al tiempo que el documental español en primera persona desborda sus canales de difusión habituales (cine doméstico y de vanguardia) como bien demuestra la recién galardonada en los Goya Muchos hijos, un mono y un castillo (Salmerón, 2017). Hasta los años noventa no se produciría en España este giro autobiográfico: cuestión ligada a la implementación de innovaciones técnicas y el peso de la tradición etnográfica en los propios documentalistas. En este sentido, autores como José Luis Guerín o Joaquim Jordà serían los primeros en incorporar su yo como claves de enunciación en sus obras.

La narración en primera persona es, así, una de las prácticas predominantes de nuestra cultura mediática actual y responde, por otra parte, a un proceso mayor: la recolocación de la subjetividad en el centro de nuestras prácticas como sociedad. El mundo de los afectos y las emociones se ha convertido en el centro discursivo por excelencia, así como en garantía de autenticidad del pacto narrativo establecido con el receptor (fenómeno que, al margen del audiovisual, encuentra en Internet y redes sociales sus mayores cauces de expansión). Este auge ha sido impulsado por

5 Discurso de León Siminiani en la narración en off de Mapa (Siminiani, 2012). 
el avance tecnológico consolidado en la última década: la popularización de las cámaras digitales y el aligeramiento de los equipos han resultado esenciales para su conversión en instrumentos de representación personal. Las conquistas técnicas son también responsables de una mayor libertad formal en la representación: la soñada cámera-stylo de Alexandre Astruc se materializa gracias a la digitalización.

La práctica autobiográfica hunde sus raíces en la ruptura del modelo de yo clásico de la modernidad y emerge como un modo de reparación y resistencia a un yo disgregado. La fragmentación del sujeto anunciada por la posmodernidad choca con una tensión en sentido contrario: la voluntad de reconstruir la unidad perdida desde una perspectiva actualizada y desprovista de esencialismos. En este sentido, la ficción, entendida como estrategia de orden y estructura, se descubre como herramienta fundamental a la hora de generar una estrategia de continuidad en el sujeto, que reelabora su historia personal desde la conciencia de la fugacidad de categorías fundamentales como historia o memoria. En consecuencia, la autobiografía cumple una función reparadora del sujeto y de constatación de sí mismo, siendo la filmación autobiográfica parte de la estrategia para incidir sobre la propia vida, gracias al efecto sobre lo real de la cámara.

Por su parte, el cineasta León Siminiani juega a ser actor y comediante dentro de su película. Por esta razón Mapa es un experimento bajo una nueva forma de libertad: la de entenderse a uno mismo como personaje sin dejar de ser el director, tanto diegética como extradiegéticamente. Gracias a este enfoque el cineasta devuelve la dimensión lúdica a su vida y consigue avistar una salida a su crisis personal, continuando la estética del fracaso ya promovida por films como A complete history of my sexual failures (Chris Waitt, 2008) o True love (De Sosa, 2011). El deseo de explorar los itinerarios de una vida filmada prevalece sobre unas dificultades que, como es bien sabido, son también el detonante de una buena historia.

La comedia y la ironía conforman el tono de este documental autoficcional: registros que constituyen una modalidad de distanciamiento idónea para interpretar la realidad personal del cineasta. En esta línea, ridiculizar el yo a través de un personaje caricaturizado es una estrategia plenamente reparadora para su agente, quien se ejercita en la órbita del ridículo y asume de forma inteligente su debilidad. Al mismo tiempo, exhibir los trapos sucios supone un desafío a la idea de uno mismo como su mejor yo: al menos, contra la idea del yo como instancia acabada y fija que debe presentarse ante el mundo.

El cine autoficcional se halla en diálogo permanente con una paradoja: para hablar de sí mismo debe señalar a un otro, a veces exterior y otras veces interior. La figura de la otredad objetiva, así, las contradicciones internas del personaje y prueba la dificultad para presentarse como un yo único y estable. Este conflicto es el detonante del desdoblamiento en Mapa: solución que ayuda al cineasta pero también al hombre, escindido ante una contrariedad que sólo sabe resolver exteriormente.

La focalización interna fija y el relato en off son las estrategias de autorrepresentación de este documental Ambas permiten al cineasta establecer un diálogo especular con imágenes ajenas, donde la voz narrativa se descubre crucial para el anclaje autobiográfico. La fractura interior del cineasta se representará mediante un desdoblamiento de la voz narrativa, escindida a su vez en dos entonaciones diferentes. Esta representación polifónica de la conciencia establece estimulantes relaciones con las 
nociones de dialogismo y alteridad de Mijaíl Bajtín, pues esboza una comprensión del sujeto en continuo diálogo con lo ajeno. Asimismo, la comprensión lúdica y performativa del cine documental demuestran un peso determinante en la construcción del discurso de Mapa: la transformación del cineasta acontece cuando renuncia a su condición de director en favor del personaje-actor.

La singularidad de este film reside en su comprensión cinematográfica de la vida. La estructura que habitualmente rige la construcción de ficción funciona, en este caso, como impulsora de acción en la crisis personal de su autor. Se prueba así una ósmosis total entre cine y vida donde el sentido de progresión dramática impone, paradójicamente, los avances de la búsqueda vital.

\section{Referencias bibliográficas}

Alberca, M. (2007). El pacto ambiguo. De la novela autobiográfica a la autoficción. Madrid: Biblioteca Nueva.

Arfuch, L. (2006). El espacio biográfico. Dilemas de la subjetividad contemporánea. Argentina: Fondo de Cultura Económica.

Bajtín, M. (1963). Problemas de la poética de Dostoievski. México: Fondo de Cultura Económica.

Bergala, A. (2008). Si yo me fuera contado. En G. Martín Gutiérrez (coord.), Cineastas frente al espejo (pp. 27-33). Madrid: T\&B.

Casas, A. (2014). El yo fabulado: nuevas aproximaciones críticas a la autoficción. España: Iberoamericana.

Colonna, V. (2004). Cuatro propuestas y tres deserciones (tipologías de la autoficción). En A. Casas (ed.), La autoficción: reflexiones teóricas (pp. 85-122). Madrid: Arco.

Corbett, K. J. (2016). Beyond Po-Mo: The "Auto-Fiction” Documentary. Journal of Popular Film and Television, 44(1), 51-59.

Cuevas,E. (2010). El cine autobiográfico en España: una panorámica. Rilce, 28(1), 106-125.

De la Torre, M. (2015). Cines del yo: el documental autoficcional contemporáneo español. Granada: Universidad de Granada.

Doubrovsky, S. (1977). Fils. París: Gallimard.

Font, D. (2008). A través del espejo: cartografías del yo. En G. Martín Gutiérrez (coord.), Cineastas frente al espejo (pp. 33-51). Madrid: T\&B.

Forceville, C. (2006). The source-path-goal schema in the autobiographical journey documentary. New Review of Film and Television Studies, 4(3), 241-261.

Foucault, M. (1994). Hermenéutica del sujeto. Madrid: Ediciones de La Piqueta.

Gaudreault, A., y Jost, F. (1995). El relato cinematográfico: cine y narratología. Barcelona: Paidós. 
Genette, G. (1989). Figuras III. Barcelona: Lumen.

Gómez, A. (2015). La transparencia de un diario audiovisual de ficción: Mapa (2012), de Elías León Siminiani. Signa, 24(1), 361-374.

Gómez, I. (2015). Mapa(s) sin territorio: un paseo por la autoficción de Elías León Siminiani. Pasavento. Revista de Estudios Hispánicos, 3(1), 109-122.

Imbert, G. (2010). Cine e imaginarios sociales: el cine posmoderno como experiencia de los límites. Madrid: Cátedra.

Lagos, P. (2011). Ecografías del yo: Documental autobiográfico y estrategias de (auto)representación de la subjetividad. Comunicación y Medios, 24(1), 60-80.

Lane, J. (2002). The Autobiographical Documentary in America. Wisconsin: University of Wisconsin Press.

Lejeune, P. (1994). El pacto autobiográfico y otros estudios. Madrid: Megazul-Endymion.

Lindig, E. (2009). El sujeto discursivo: la construcción social de subjetividades en el pensamiento de Bajtín y su Círculo. Acta Poética, 30(1), 55-70.

Martín Gutiérrez, G. (2008). Entre el reflejo y la sombra. Estrategias del yo en el cine. En G. Martín Gutiérrez (coord.), Cineastas frente al espejo (pp. 53-63). Madrid: T\&B.

Morin, E. (1970). El hombre y la muerte. Barcelona: Kairós.

Piedras, P. (2010). La cuestión de la primera persona en el documental latino contemporáneo. La representación de lo autobiográfico y sus dispositivos. Cine y documental. Recuperado de http://revista.cinedocumental.com.ar/1/articulos_04.html

Pozuelo Yvancos, J. M. (2013). Figuraciones del yo en la narrativa. Valladolid: Universidad de Valladolid.

Quílez, L. (2008). Sutiles pretéritos: (post)memoria(s) y (auto)biografía(s) en el cine documental contemporáneo. En G. Martín Gutiérrez (coord.), Cineastas frente al espejo (pp. 83-97). Madrid: T\&B.

Sánchez-Mesa, D. (1999). Literatura y cultura de la responsabilidad: el pensamiento dialógico de Mijaíl Bajtín. Granada: Comares.

Sánchez-Mesa, D., y Baetens, J. (2017). La literatura en expansión. Intermedialidad y transmedialidad en el cruce entre la Literatura Comparada, los Estudios Culturales y los New Media Studies. Tropelías. Revista de Teoría de la Literatura y Literatura Comparada, 27(1), 6-27.

Siminiani, L. (2012). ¿Hacia una poética de la contradicción? Territorios y fronteras: experiencias documentales contemporáneas. Recuperado de https://web-argitalpena.adm.ehu.es/pdf/UWEB0146652.pdf

Siminiani, L. (2012). Mapa [DVD]. España: Avalon.

Torreiro, C. (2010). Realidad y creación en el cine de no ficción. Madrid: Cátedra.

Weinrichter, A. (2004). Desvíos de lo real: el cine de no ficción. Madrid: T\&B. 